\title{
Effect of cattle liquid manure fertilization on the yield of grassland and density of soil oribatid mites (Acari, Oribatida)
}

\author{
KAROLINA KRUCZYŃSKA and STANISŁAW SENICZAK \\ Department of Ecology, University of Technology and Life Sciences in Bydgoszcz, \\ Kordeckiego 20, 85-225 Bydgoszcz, Poland \\ Corresponding author: Karolina Kruczyńska, karla318@wp.pl
}

(Received on 29 March 2010; Accepted on 11 October 2010)

\begin{abstract}
The effect of cattle liquid manure without and with Effective Microorganisms (EM) on the hay yield and density of soil Oribatida was investigated in a lowland meadow. Fertilization of the meadow with low and medium doses $\left(30 \mathrm{~m}^{3} \cdot \mathrm{ha}^{-1}\right.$ and $\left.60 \mathrm{~m}^{3} \cdot \mathrm{ha}^{-1}\right)$ of liquid manure increased the hay yield, more with EM than without them. However, the highest dose $\left(90 \mathrm{~m}^{3} \cdot \mathrm{ha}^{-1}\right)$ of fertilizer did not change hay yield, as compared to the control plot. All doses of cattle liquid manure reduced the density of oribatid mites, distinctly more without EM than with them. This suggests a favourable influence of EM on these mites. Among the Oribatida, Liebstadia similis, Scheloribates laevigatus, Eupelops occultus, and Achipteria coleoptrata, were abundant, while other species were infrequent. The community of Oribatida was dominated by adults.
\end{abstract}

Keywords: cattle liquid manure, Effective Microorganisms, grassland, hay yield, Oribatida

\section{INTRODUCTION}

Industrial farms generate huge amounts of liquid manure, which creates environmental problems. It is difficult to store, and when stored improperly, it soaks into the soil, with pathogenic microbes and some parasites. Liquid manure is rich in nutrients that are necessary for plant growth, but in higher concentrations it limits plant growth. Liquid manure can be used as a fertilizer, but it has some pathogenic microbes and parasites of domestic animals, and therefore it should preferably be disinfected before use. Several chemical disinfectants were used for many years, but they limit microbial growth also in the soil. Alternative disinfectants are Effective Microorganisms (EM), which contain only certain tribes of microorganisms, limiting the development of pathogenic microbes and parasites of domestic animals.

Oribatid mites are numerous inhabitants of the upper soil layers, and can be used as indicators of microbial activity in the soil (TISCHLER 1971). Most of them decom- 
pose the soil organic matter, transform it into humus, and mix it with the mineral soil, increasing the soil fertility (BOCZEK 1958; BURGES \& RAW 1971) and plant crop.

The aim of this experiment was to determine the effects of various doses of cattle liquid manure, without and with Effective Microorganisms, on hay yield and abundance of oribatid mites in a lowland meadow.

\section{MATERIAL AND METHODS}

The experiment was conducted in a hay meadow located in the Bydgoski Canal valley, between Bydgoszcz and Nakło (northern Poland). The meadow belongs to the Agricultural Experimental Station at Minikowo, owned by the University of Technology and Life Sciences in Bydgoszcz. Seven experimental plots were established(Fig. 1), each of $20 \mathrm{~m}^{2}(4 \mathrm{~m} \times 5 \mathrm{~m})$, separated by 4 -m buffer zones. One plot was a control $(0)$

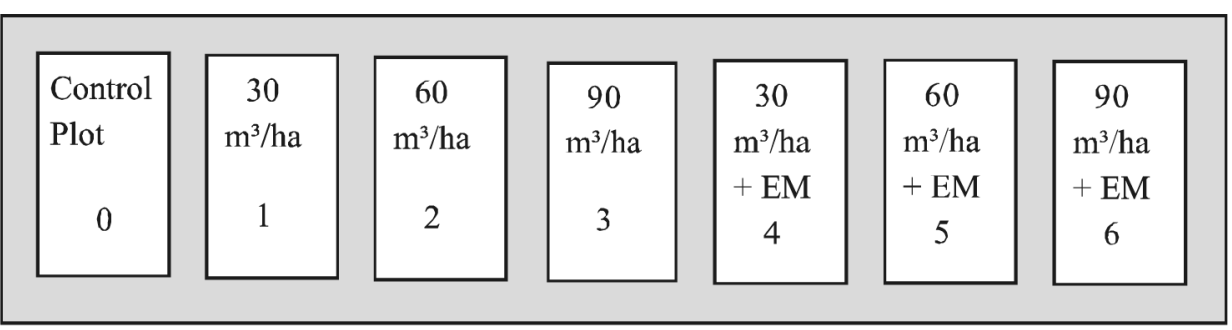

Fig. 1. Experimental design - plots in the investigated meadow. Dose of cattle liquid manure: $30-90 \mathrm{~m}^{3} / \mathrm{ha}$

and three $(1,2,3)$ were fertilized in the first decade of May and August of 2008 with cattle liquid manure in doses of $30 \mathrm{~m}^{3} \cdot \mathrm{ha}^{-1}, 60 \mathrm{~m}^{3} \cdot \mathrm{ha}^{-1}$, and $90 \mathrm{~m}^{3} \cdot \mathrm{ha}^{-1}$, respectively, and the remaining three $(4,5,6)$ were fertilized with the same doses of cattle liquid manure but with Effective Microorganisms (EM), which are sold by Greenland Technology Co. The EM were used in concentration $1 \mathrm{dm}^{3} / 1 \mathrm{~m}^{3}$ of liquid manure. Turf samples of $50 \mathrm{~cm}^{3}$ each $\left(17 \mathrm{~cm}^{2}\right.$ in area, height $9 \mathrm{~cm}$, including about $3 \mathrm{~cm}$ of lower parts of grasses and about $6 \mathrm{~cm}$ of top soil) were taken from each plot in the last decade of May and September of 2008 in 10 replications. Oribatid mites were extracted from the samples in Tullgren funnels, next preserved, and determined to species level, including the juveniles. Names of species follow WeIGMANN (2006). The species were characterised with the abundance $(A)$, dominance $(D)$, and constancy $(C)$ indices, while the oribatid mite communities were compared with the Shannon index $H$ (ODUM 1971). The results were verified using the $U$ Mann-Whitney test at $P \leq 0.05$ (Statistica 6.0), after logarithmic transformation of data (BERTHeT \& GERARD 1965; STATSoft 2006). 


\section{RESULTS AND DISCUSSION}

Lower doses of cattle liquid manure $\left(30 \mathrm{~m}^{3} \cdot \mathrm{ha}^{-1}\right.$ and $\left.60 \mathrm{~m}^{3} \cdot \mathrm{ha}^{-1}\right)$ increased the hay yield, while the highest dose $\left(90 \mathrm{~m}^{3} \cdot \mathrm{ha}^{-1}\right)$ did not change it, as compared to the control plot (Table 1). However, low and medium doses of fertilizer with EM increased the hay yield more $(43.2 \%$ and $55.2 \%$, respectively) than without EM (12.8\% and $45.6 \%$, respectively). This suggests that EM increased soil fertility. The hay from fertilized plots was richer in crude proteins and crude fibre, but poorer in crude fat, N-free extract, and crude ash, as compared to the control. This is consistent with results presented by Kostuch (1982) and Domek-Chruścicka \& Seniczak (2005).

Table 1. Annual hay yield and chemical composition of dry matter in the plots investigated

\begin{tabular}{|c|c|c|c|c|c|c|c|}
\hline \multirow{2}{*}{ Hay characteristics } & \multicolumn{7}{|c|}{ Plot } \\
\hline & 0 & 1 & 2 & 3 & 4 & 5 & 6 \\
\hline Hay yield $\left(\mathrm{t} \cdot \mathrm{ha}^{-1}\right)$ & 4.2 & 4.7 & 6.1 & 4.1 & 6.0 & 6.5 & 4.3 \\
\hline Crude proteins $(\%)$ & 9.96 & 10.55 & 13.29 & 12.15 & 11.72 & 13.55 & 16.13 \\
\hline Crude fat $(\%)$ & 2.67 & 2.64 & 2.73 & 2.71 & 2.58 & 3.02 & 3.06 \\
\hline Crude fibre $(\%)$ & 34.24 & 36.61 & 35.67 & 36.49 & 37.29 & 33.93 & 34.04 \\
\hline $\mathrm{N}$-free extract $(\%)$ & 46.87 & 44.30 & 41.19 & 42.63 & 42.93 & 42.63 & 39.27 \\
\hline Crude ash (\%) & 6.26 & 5.90 & 7.12 & 6.02 & 5.48 & 6.87 & 7.50 \\
\hline
\end{tabular}

Fertilization of the meadow with cattle liquid manure reduced the density of oribatid mites (Table 2), more strongly if applied without EM than with them. This indicates that EM is favourable for mites, in contrast to chemical disinfectants, which reduced the density of Oribatida in an earlier study (GrACZYK et al. 2008). Similarly, Bielska (1986), Trojanowski \& Baluk (1992) and GraczyK et al. (2010) also observed a negative reaction of Oribatida to the highest dose of liquid manure. This reaction is probably caused by the negative influence of ammonia, which is released from liquid manure and is toxic to soil mites (WARREN 1962). The cattle liquid manure did not affect the number of species of Oribatida (10-11 species were found in each plot), but slightly increased the Shannon index $H$ in all fertilized plots, which also suggests a higher soil fertility.

Among the recorded Oribatida, the most abundant were Liebstadia similis (Michael, 1888), Scheloribates laevigatus (C. L. Koch, 1835), Eupelops occultus (C. L. Koch, 1835) and Achipteria coleoptrata (Linnaeus, 1758), which had also a high constancy index (Table 2). All these species reacted negatively to cattle liquid manure fertilization, as their density decreased in fertilized plots, as compared to the 
Table 2. Abundance $\left(A\right.$, in $10^{3}$ individuals $\cdot \mathrm{m}^{-2}$; juv $=$ juveniles $)$, number of species $(S)$, and Shannon index $(H)$ of total Oribatida, and abundance, dominance ( $D$, in $\%$ of total catch), and constancy $(C$, in $\%$ of total samples) indices of major species in the plots investigated

\begin{tabular}{|c|c|c|c|c|c|c|c|c|}
\hline \multirow{2}{*}{ Species } & & \multicolumn{6}{|c|}{ Plots } & \multirow[b]{2}{*}{6} \\
\hline & & 0 & 1 & 2 & 3 & 4 & 5 & \\
\hline \multirow[t]{4}{*}{ Oribatida } & $A$ & 21.6 & 18.0 & 17.4 & $14.0^{*}$ & 19.7 & $21.5^{\mathrm{c}}$ & $15.0^{*}$ \\
\hline & $A$ juv & 4.5 & 3.2 & 3.1 & $2.3^{*}$ & 4.1 & 3.8 & $2.7 *$ \\
\hline & $S$ & 10 & 11 & 11 & 11 & 11 & 11 & 11 \\
\hline & $H$ & 1.64 & 1.68 & 1.76 & 1.72 & 1.67 & 1.68 & 1.70 \\
\hline \multirow{4}{*}{$\begin{array}{l}\text { Liebstadia } \\
\text { similis }\end{array}$} & $A$ & 8.6 & 6.4 & 6.0 & 4.9 & 7.6 & 8.2 & 5.5 \\
\hline & $A$ juv & 2.2 & 1.5 & 1.3 & $1.0^{*}$ & 1.9 & 1.6 & $1.3 *$ \\
\hline & $D$ & 40.0 & 35.4 & 34.8 & 34.9 & 41.0 & 38.6 & 36.7 \\
\hline & $C$ & 100 & 100 & 100 & 100 & 100 & 100 & 100 \\
\hline \multirow{4}{*}{$\begin{array}{l}\text { Scheloribates } \\
\text { laevigatus }\end{array}$} & $A$ & 4.3 & 4.2 & 3.6 & 3.2 & 3.7 & 4.4 & 3.2 \\
\hline & $A$ juv & 0.9 & 0.9 & 0.9 & 0.7 & 0.7 & 0.7 & 0.6 \\
\hline & $D$ & 19.8 & 24.0 & 21.4 & 22.4 & 18.7 & 21.5 & 21.2 \\
\hline & $C$ & 100 & 100 & 100 & 100 & 100 & 100 & 90 \\
\hline \multirow{4}{*}{$\begin{array}{l}\text { Eupelops } \\
\text { occultus }\end{array}$} & $A$ & 3.9 & 3.5 & 3.4 & 3.1 & 3.8 & 3.7 & 2.8 \\
\hline & $A$ juv & 0.9 & 0.7 & 0.7 & 0.6 & 0.8 & 0.7 & 0.6 \\
\hline & $D$ & 18.0 & 20.4 & 19.9 & 21.8 & 18.7 & 17.2 & 19.1 \\
\hline & $C$ & 100 & 100 & 100 & 100 & 100 & 100 & 100 \\
\hline \multirow{4}{*}{$\begin{array}{l}\text { Achipteria } \\
\text { coleoptrata }\end{array}$} & $A$ & 2.2 & $1.2 *$ & 1.3 & $0.7^{*}$ & $1.9^{\mathrm{c}}$ & $2.1^{\mathrm{c}}$ & $1.2 *$ \\
\hline & $A$ juv & 0.4 & 0.2 & 0.2 & $0 *$ & $0.4^{c}$ & $0.4^{\mathrm{c}}$ & 0.1 \\
\hline & $D$ & 10.1 & 6.6 & 7.3 & 5.1 & 9.1 & 10.0 & 7.6 \\
\hline & $C$ & 100 & 100 & 90 & 80 & 80 & 100 & 80 \\
\hline
\end{tabular}

Significant differences at $P \leq 0.05$ between: * control plot and plots $1-6 ;{ }^{\text {a }}$ plot 1 and plots $2-6$; ${ }^{\mathrm{b}}$ plot 2 and plots $3-6 ;{ }^{\mathrm{c}}$ plot 3 and plots $4-6 ;{ }^{\mathrm{d}}$ plot 4 and plots $5-6$; ${ }^{\mathrm{e}}$ plot 5 and plot 6.

control plot. This decrease was more evident in plots fertilized with only cattle liquid manure than with this fertilizer and EM, which indicates that EM is favourable for these species. Liebstadia similis and Eupelops occultus were more sensitive to this fertilizer than Scheloribates laevigatus, which increased its dominance index on most fertilised plots, as compared to the control. 
In all plots the adults highly dominated (79.2-83.6\% of the community). The fertilization generally reduced the density of juveniles, more after the fertilization with only cattle liquid manure than with this fertilizer and EM. Among the most abundant species, the most sensitive to this fertilizer were the juveniles of Liebstadia similis. GRACZYK et al. (2008) observed a positive effect of a low dose of cattle liquid manure $\left(40 \mathrm{~m}^{3} \cdot \mathrm{ha}^{-1}\right)$ on the density of juvenile oribatid mites, but higher doses of fertilizer reduced their density, as compared to the control plot. Oribatid species typical of meadows may, however, create economic problems, because they are intermediate hosts of tapeworms (RAJSKI 1959; DENEGRI 1993), which parasitize some domestic and wild animals.

\section{CONCLUSIONS}

Fertilization of meadows with low and medium doses of cattle liquid manure increased the hay yield, more strongly when applied with Effective Microorganisms (EM) than without them. However, the highest dose of fertilizer did not change hay yield, as compared to the control plot. All doses of cattle liquid decreased the density of oribatid mites, distinctly more strongly without EM than with them. This suggests a favourable influence of EM on these mites. Typical meadow species, like Liebstadia similis, Scheloribates laevigatus, Eupelops occultus, and Achipteria coleoptrata, were the most abundant among oribatid mites, while other species were infrequent. Their populations were represented mainly by adults.

\section{REFERENCES}

Berthet P., Gerard G. 1965. A statistical study of microdistribution of Oribatei (Acari). Part I. The distribution pattern. Oikos 16: 214-227.

BIELSKA I. 1986. Communities of moss mites (Acari, Oribatei) of chosen grasslands periodically flooded with liquid manure. Pol. Ecol. Stud. 12: 163-178.

BoczeK J. 1958. Soil mites (Acarina) and their participation in the creation of humus. Post. Nauk Roln. 4: 33-41.

Burges A., Raw F. 1971. Biologia gleby [Soil biology]. PWRiL, Warszawa (in Polish).

DENEGRI G. M. 1993. Review of oribatid mites as intermediate hosts of tapeworms of the Anoplocephalidae. Exp. Appl. Acarol. 17: 567-580.

Domek-Chruścicka K., SeniczaK S. 2005. Effect of swine slurry fertilization on the yield of temporary grassland and the density of some groups of mesofauna. Zesz. Nauk. 245, ATR Bydgoszcz, Zootechnika 35: 47-53.

Graczyk R., Seniczak S., Wasińska-Graczyk B. 2008. The effect of cattle liquid manure fertilization on the soil mites (Acari) of permanent meadow in Poland. J. Cent. Eur. Agric. 9: 651-658.

Graczyk R., Seniczak S., WasińsKa-Graczyk B. 2010. The effect of cattle liquid manure fertilization on seasonal dynamics of Oribatida (Acari) in a permanent lowland meadow in Poland. Biological Lett. 47: 59-64.

Kostuch R. 1982. Przemienne użytki zielone [Alternating grassland]. PWRiL, Warszawa (in Polish). 
Odum E. P. 1971. Podstawy ekologii [Principles of ecology]. W. B. Saunders Co., Georgia (in Polish).

RAJSKI A. 1959. Mechowce (Acari: Oribatei) jako żywiciele pośredni tasiemców (Cestodes: Anoplocephalata) w świetle literatury [Moss-mites (Acari: Oribatei) as intermediate hosts of Anoplocephalata: a review]. Zesz. Nauk. UAM Biol. 2: 163-192 (in Polish).

StatSoft 2006. Elektroniczny Podręcznik Statystyki [Electronic textbook of statistics]. Kraków (in Polish). http://www.statsoft.pl/textbook/stathome.html.

Tischler W. 1971. Agroekologia [Agroecology]. PWRiL, Warszawa (in Polish).

Trojanowski H., Baluk A. 1992. Wpływ nawożenia azotowego na drobne bezkręgowce glebowe - roztocze (Acarina) i skoczogonki (Collembola) [The effect of nitrogen fertilization on small soil invertebrates - Acarina and Collembola]. Rocz. Nauk. Rol. E 22: 83-90.

WARREN K. S. 1962. Ammonia toxicity and pH. Nature (London) 195: 47-49.

Weigmann G. 2006. Hornmilben (Oribatida) [Oribatid mites]. In: Die Tierwelt Deutschland und der angrenzenden Meeresteile. 76. Teil (DAHL F., Ed), pp. 1-520, Goecke \& Evers, Keltern (in German). 